\title{
Oman osaamisen tunnistaminen voimaantumisen välineenä
}

\author{
Anne Airaksinen
}

\section{TIIVISTELMÄ}

- Tässä katsauksessa tarkastellaan oman osaamisen tunnistamista voimaantumisen näkökulmasta. Tarkastelussa hyödynnetään ViaDia Joensuu ry:n Kotoa kohti työelämää -hankkeessa vuosina 2019-2020 saatuja kokemuksia. Hankkeen toiminta kohdennettiin maahan muuttaneille naisille ja toiminta tavoitti säännöllisesti noin 40 osallistujaa. Hankkeessa toteutettiin avoimia toiminnallisia ryhmä- ja yksilöohjaustuokioita, joiden avulla tuettiin osallistujien suomen kielen taitoa ja tunnistettiin osallistujien vahvuuksia sekä kartoitettiin heidän opiskelumahdollisuuksiaan. Hankkeen tarkoituksena oli tukea osallistujien omien lähtökohtien ja tarpeiden pohjalta osallistujien voimavaroja, potentiaalia, kasvua, osallisuutta ja toimijuutta. Toiminnan taustalla on tunnistettavissa sosiaalipedagoginen viitekehys.

Osaamisen tunnistamisen työvälineinä käytettiin Itä-Suomen yliopiston SkiLLfie-itsearviointityökaluja, jotka auttavat tunnistamaan ja sanoittamaan omaa osaamista sekä kertomaan siitä. SkiLLfie-työkalut on kehitetty erityisesti maahan muuttaneiden tarpeisiin. Tässä katsauksessa hyödynnetään hankkeen aikana kertyneiden kokemusten lisäksi hanketyöntekijöiden laatimaa aikuiskasvatustieteen pro gradu -työtä, joka käsittelee Itä-Suomen yliopiston Opinsauna-hankkeen oman osaamisen tunnistamisen työkalujen käytön vaikutuksia. Oman osaamisen tunnistamista lähestytään voimaantumisen ydinkäsitteen kautta.

Avainsanat: kotoutuminen, maahanmuuttajat, osaamisen tunnistaminen, voimaantuminen. 


\section{ABSTRACT}

\section{SELF-RECOGNITION OF SKILLS AS A TOOL OF EMPOWERMENT}

- This study examines self-recognition of skills from the perspective of empowerment. The examination utilizes experiences between 2019 and 2020, retrieved from the From Home Towards Working Life project by the ViaDia association in Joensuu. The activities through the project were focused on immigrant women and reached around 40 participants regularly. From Home Towards Working Life implemented open and functional group and individual counselling sessions, which supported the Finnish language skills of the participants and helped them identify their strengths and determine their study opportunities in Finland. The purpose of the project was to support the participants' resources, potential, growth, participation and agency on the basis of their starting points and needs. A socio-pedagogic framework can be seen as the background to these activities.

The tools used for the recognition of skills were the University of Eastern Finland's SkiLLfie, a toolset which helps in identifying and expressing one's skills. SkiLLfie has been developed for the needs of immigrants in particular. In addition to the experiences logged during the time of the project, this examination utilizes an adult education Master's thesis, written by workers from the project, that covers the effects of using self-recognition of skills tools from the Opinsauna project of the University of Eastern Finland. This study takes an approach to the self-recognition of skills through the core concept of empowerment.

Keywords: integration, immigrants, recognition of skills, empowerment

\section{Johdanto}

$\mathrm{V}$ iaDia Joensuu ry:llä on vuosien kokemus monikulttuurisesta työstä etenkin maahan muuttaneiden äitien kanssa. Rantakylän Lähiötalo on kohtaamispaikka erityisesti lapsiperheille ja koululaisille, ja viime vuosina toimintaan osallistuneista $10-15$ prosenttia on ollut monikulttuurisia kävijöitä. Kotoa kohti työelämää -hankkeen idea pohjautuu ViaDia Joensuu ry:n aiempaan monikulttuuriseen toimintaan ja kokemuksiin: kohtaamispaikkatoiminnassa nousi esille tarve entistä kohdennetummasta suomen kielen opetuksesta, jonka lisäksi osallistujat kaipasivat tietoa suomalaisen yhteiskunnan tarjoamista mahdollisuuksista opiskeluun ja työelämään. Näin syntyi idea kehittää maahan muuttaneille naisille suunnattua hyvinvointia tukevaa hanketoimintaa. 
Kotoa kohti työelämää -hanke (1.2.2019-31.1.2020) sai rahoituksensa Joensuun KAKE 2.0 -hankkeen (2.1.2018-31.12.2021) kautta, jonka tarkoituksena on tukea osallisuutta edistäviä kehittämishankkeita. Joensuun KAKE 2.0 -hanketta rahoittavat Joensuun kaupunki, Etelä-Savon ELY-keskus sekä Euroopan sosiaalirahasto. Kotoa kohti työelämää -hanke mahdollisti käytännössä kaksi säännöllisesti viikoittain kokoontuvaa ryhmää Rantakylän Lähiötalolla: toisen ryhmän työskentelyssä keskityttiin suomen kielen opiskeluun sekä kielitaidon tukemiseen, kun toisessa ryhmässä keskityttiin oman tulevaisuuden suunnitteluun. Ryhmätoimintojen lisäksi osallistujille tarjottiin yksilöllistä tukea ja ohjausta. Lisäksi tehtiin retkiä ja tutustumiskäyntejä eri kohteisiin, osallistujien tarpeiden ja mielenkiinnon mukaan. Toiminta oli kaikille avointa matalan kynnyksen toimintaa. Rantakylän Lähiötalolle järjestetyn lastenhoidon myötä myös kotona lapsiaan hoitavilla äideillä oli mahdollisuus tulla mukaan. Ennakkoilmoittautumista tai kielitaitovaatimuksia osallistumiselle ei ollut. Toiminnan tarkoituksena oli muun muassa antaa mahdollisuus oman identiteetin tarkasteluun ja vahvistamiseen, omien vahvuuksien löytämiseen ja itsetunnon lisäämiseen sekä suomen kielen taitojen kartuttamiseen.

Hankkeen toiminta muotoutui osallistujien omista tarpeista käsin: yksilöllisesti, innostavasti ja voimavaralähtöisesti. Hankkeen toimintaa kehitettiin kaksisuuntaista kotoutumista tukevasta näkökulmasta: kuinka yksilö voisi rakentaa omaa identiteettiään, löytää omat vahvuutensa ja oman polkunsa elinympäristössään - ja toisaalta, kuinka aktivoida ympäröivää yhteiskuntaa vastaanottamaan ja huomioimaan yhä monimuotoistuvaa väestöä. Yksilön omat kiinnostuksen kohteet ja osaamisalueet pyrittiin nostamaan esille ja saamaan käyttöön siten, että yksilö tulisi tietoiseksi omista voimavaroistaan ja potentiaalistaan. Hankkeen toiminnan kannalta olennaista oli, että osallistujat yhdessä tekivät toiminnasta oman näköisensä. Työelämän ja opiskelun lisäksi koettiin tärkeäksi huomioida myös muita hyvinvoinnin kannalta tärkeitä osallistumisen paikkoja, joissa omaa osaamista olisi mahdollista hyödyntää, kuten järjestö- ja yhdistystoiminta sekä harrastukset. Eri tahoja pyrittiin myös aktivoimaan; hanketoiminnassa työskenneltiin useiden eri sidosryhmien ja yhteistyökumppaneiden kanssa.

Oman osaamisen ja vahvuusalueiden tunnistaminen oli luonteva osa hankkeen voimavaralähtöistä työskentelyotetta, sillä oman osaamisen tunnistamisella voidaan nähdä olevan yhteys kotoutumiseen: Ager ja Strang (2008) ovat tunnistaneet potentiaalisia kotoutumisen indikaattoreita, joista yksi on osaaminen (erityisesti kielellinen ja kulttuurinen osaa- 
minen). Sen lisäksi muita indikaattoreita ovat muun muassa työ, koulutus ja sosiaaliset yhteydet (Ager \& Strang 2004, 13). Kielen ja kulttuurin osaaminen on yksi kotoutumisen edellytys, mutta myös muunlaisen osaamisen avulla voi päästä erilaisten aktiviteettien piiriin, joiden avulla on mahdollista edistää sosiaalisten yhteyksien muodostumista Suomessa. Näitä ovat esimerkiksi vapaa-ajan harrastukset. Sosiaalisten siltojen ja yhteyksien syntyminen edesauttaa kotoutumista ja mahdollistaa työllistymisen tai opiskelun (Ager \& Strang 2008). Onkin hyvä huomioida, että esimerkiksi työllistyminen ei siis yksin ole tae onnistuneesta kotoutumisesta (Työ- ja elinkeinoministeriö 2020).

Oman osaamisen ja vahvuusalueiden tunnistamisessa hyödynnettiin SkiLLfie-itsearviointityökaluja. Itä-Suomen yliopiston Opinsauna-hanke on kehittänyt työkalut yhteistyössä Opintokeskus Siviksen, Karelia ammattikorkeakoulun sekä aikuisten maahan muuttaneiden henkilöiden kanssa. Työkalut on kehitelty erityisesti maahan muuttaneiden tarpeisiin: tarkoituksena on auttaa tunnistamaan ja sanoittamaan omaa osaamista sekä kertomaan siitä muille. Työkaluja on saatavilla eri kieliversioina (suomi, englanti, dari, arabia, somali) ja niitä voidaan käyttää niin verkko- kuin mobiiliversiona (Android) tai paperille tulostettuina. Työkalut on julkaistu kaikkien kiinnostuneiden käyttöön verkossa. (Itä-Suomen yliopisto 2020.)

Kotoa kohti työelämää -hankkeessa työskenteli kaksi työntekijää, joista toinen on tämän katsauksen kirjoittaja. Työskentelimme yhdessä myös Opinsauna-hankkeessa ja olimme mukana SkiLLfie-itsearviointityökalujen kehittämisessä ja arvioinnissa (Airaksinen \& Aittamaa 2019).

\section{Osaamisen tunnistamisesta voimaantumiseen}

Osaaminen tarkoittaa kaikkia niitä tietoja, taitoja ja kompetensseja, joita yksilö on elämänsä aikana hankkinut. Ne ovat kertyneet kokonaisuuden osiksi eri lähteistä. (Pusa 2017.) Yksilön osaaminen muodostuu siis tiedoista, taidoista, kokemuksesta, verkostoista ja kontakteista, asenteesta sekä henkilökohtaisista ominaisuuksista, jotka auttavat selviytymään kulloisessakin tilanteessa ja joiden seurauksena on hyvä suoritus (Otala 2008, 50). Tässä katsauksessa osaamisen käsitteeseen sisällytetään kaikki yksilön omaamat tiedot, taidot ja kompetenssit, jotka on hankittu eri tavoin, formaalisti, nonformaalisti ja informaalisti.

Kun oma osaamisen ensiksi tunnistetaan, on sen jälkeen mahdollista kertoa siitä. Eri tavoin hankittu tunnistettu osaaminen kyetään tarvit- 
taessa nostamaan esille, ja siitä on mahdollista viestiä kohdennetummin. Osaamisen tunnistaminen voi siis tarkoittaa prosessia, jossa yksilö analysoi omia kokemuksiaan ja tuottaa osaamisen arvioinnissa tarvittavia materiaaleja ja todisteita osaamisestaan (Saloheimo 2008, 338).

Osaamisen tunnistamisen voidaan nähdä olevan osa osaamisen tunnustamisen prosessia. Osaamisen tunnustaminen on useimmiten sidoksissa oppilaitoksiin. Tunnustaminen voidaan tehdä oppilaitoksissa ainakin kolmella eri tavalla: tunnustamalla osaaminen koulutukseen hakeutuessa, tunnustamalla osaaminen aiempien opintojen hyväksilukuprosessin aikana tai tunnustamalla osaaminen näyttötutkinnossa. Osaamisen tunnustamisella viitataan usein sekä tunnistamisen ja tunnustamisen prosessiin että virallisen tai sosiaalisen tunnustuksen saamiseen osaamiselle. (Saloheimo 2008, 338-340.) Cedefop (2014), Euroopassa toimiva ammatillisen koulutuksen kehittämiskeskus, on määritellyt osaamisen tunnustamisen prosessiksi, jossa osaamisesta, taidoista ja kompetensseista myönnetään virallinen status. Tämä voi tapahtua tunnustamalla nonformaalia ja informaalia oppimista, tunnustamalla esimerkiksi vastaavuuksia ja opintoviikkoja koulumaailmassa tai myöntämällä tutkintoja, todistuksia tai titteleitä. Edellä mainittujen lisäksi kyseessä voi olla myös sosiaalinen tunnustaminen, jossa sosiaaliset sidosryhmät tunnustavat yksilön osaamisen arvon. Tämän sosiaalisen validoinnin tarkoituksena on osaamisen tunnistaminen ja tunnustaminen siten, että yksilö voimaantuu. Vaikka validointiin liitetään yleensä arviointia, siitä on löydettävissä hyviä käytäntöjä myös sellaiseen osaamisen tunnustamiseen, jossa ulkopuolinen arviointi ei ole lainkaan tarkoituksena. Sosiaaliseen validointiin voi siis liittyä osaamisen näkyväksi tekeminen itsen lisäksi myös lähiympäristölle. Lisäksi siihen voi kuulua jatkosuunnitelmien tekeminen. (Karttunen 2011, 14-15.)

\section{Osaamisen tunnistamisen merkitys}

Maahan muuttaneella henkilöllä voi olla edessään tilanne, jossa tuttujen ihmisten heijastamat kuvat katoavat - ne eivät enää ole tukemassa yksilön käsitystä omasta itsestään. Henkilöllä ei enää ole ympärillään ihmisiä, jotka peilaisivat hänelle sitä kuvaa, jollaiseksi hän kokee itsensä ja johon hän on aiemmin tottunut. Uusi ympäristö määrittelee tällöin yksilön eri tavoin, kuin mihin hänen oma identiteetin tunteensa on perustunut aiemmin. Ongelmana on se, että peilistä heijastuva kuva on nyt erilainen ja puutteellinen aiempaan verrattuna. Lisäksi uusi peilikuva saattaa määritellä maahan muuttanutta henkilöä kollektiivisesti, tietyn ryhmän omi- 
naisuuksien mukaan. Tällöin oman identiteetin säilyttäminen on vaikeaa. (Alitolppa-Niitamo 1993, 42-43.)

Koska maahan muuttanut ei useinkaan puhu valtakieltä, hän ei pysty kertomaan itsestään asioita muille. Uudessa ympäristössä kukaan ei tiedä hänestä mitään: ei hänen koulutuksestaan tai ammattitaidostaan, saati asioista, joissa hän on ollut hyvä ja arvostettu. (Alitolppa-Niitamo 1993, 43.) Oman osaamisen tunnistamisen työkalujen avulla henkilön on mahdollista näyttää toisille osaamistaan. Osaaminen muodostaa kokonaisvaltaisen osan henkilön identiteetistä (Wilhelmsson 2010, 27). Osaamisen tunnistaminen ei liity ainoastaan ammatillisen identiteetin hahmottamiseen vaan elämän laatuun laajemminkin (Käyhkö, Manninen \& Pitkänen 2019, 39). Osaamista ei siis tunnisteta ainoastaan työllistymisen näkökulmasta, vaan se on tärkeää yksilön kokonaisvaltaisen hyvinvoinnin kannalta (Käyhkö ym. 2019, 42).

Maahanmuuttajien kohdalla oman osaamisen tunnistamisen haasteet ja mahdollisuudet siis korostuvat, kun uutta kulttuuria ja kieltä opetellessa myös käsitys omasta osaamisesta voi merkittävästi muuttua. Erilaisissa ympäristöissä eri tavoin opitut taidot tuovat omat haasteensa osaamisen tunnistamiseen (Vakimo 2013, 79). Mikäli kotimaan ammattia ei ole enää Suomessa mahdollista harjoittaa, tarve muiden vahvuusalueiden tunnistamiselle korostuu entisestään. Lisäksi oman osaamisen itsearviointi voi toimia oman identiteetin peilinä. Kokemus omasta identiteetistä perustuu sekä yksilön omaan kokemukseen että siihen, miten ulkomaailma peilaa yksilön käyttäytymistä. Lopputuloksen kannalta vaikutusta on sillä, kuinka yhteneväisiä nämä kaksi peilikuvaa ovat.

Kun osaaminen tunnistetaan, se on mahdollista tehdä näkyväksi: myös muut ihmiset voivat nähdä sen. Tästä syystä osaamisen tunnistaminen on yhteydessä voimaantumiseen. (Wilhelmsson 2013, 32.) Myös koulutuksen ulkopuolella saavutetun osaamisen tunnistaminen on tärkeää, koska osaamisen tunnistaminen vahvistaa itseluottamusta ja oman merkityksellisyyden kokemusta. Tämä voi rohkaista esimerkiksi lisäkouluttautumiseen sekä johtaa edelleen parempiin työllistymismahdollisuuksiin (Smith \& Clayton 2009, 3), joilla voi olla hyvinvointia lisäävä vaikutus.

\section{Voimaantuminen}

Voimaantuminen (empowerment) on käsitteenä moniulotteinen ja monitulkintainen. Käsitettä eri tavoin painottamalla voidaan tavoitella erilaisia päämääriä. (Nivala \& Ryynänen 2019, 159.) Empowerment-käsite 
voidaan suomentaa lukuisin eri tavoin: käännöksiä voivat olla voimaantumisen lisäksi esimerkiksi valtaistuminen, valtautuminen sekä voimavaraistuminen. Se, mikä käännös lopulta valitaan, liittyy siihen, mitä käsitteellä halutaan ilmaista voimaantumisen ilmiön, prosessin ja lopputuloksen kannalta. (Hokkanen 2017.) Tässä katsauksessa voimaantumisen nähdään liittyvän etenkin itsensä toteuttamiseen, toimintakyvyn vahvistumiseen sekä hyvinvointiin. Tarkastelussa otetaan huomioon yksilön lisäksi myös laajempi näkökulma: kotoutuminen ymmärretään kaksisuuntaiseksi prosessiksi.

Voimaantuminen on sitä, kun ihminen luo mahdollisuuksia sekä vaikuttaa niihin asioihin, jotka liittyvät hänen elämänsä kulkuun (Zimmerman 1995, 583). Voimaantuminen voi tarkoittaa tietoisuuden lisääntymistä omasta itsestä ja suhteista sosiaaliseen ympäristöön sekä vaikutusmahdollisuuksien vahvistumista (Hänninen 2009, 5). Voimaantumisen prosessiin vaikuttaa myös sosiaalinen konteksti: sosiaalisen kontekstin kautta tapahtuva osallisuus on yksi voimaantumisen osa-alue (Cattaneo \& Chapman 2010, 647-648). Voimaantumisella tarkoitetaan siis sisäistä voimantunnetta: voimaantunut ihminen on sellainen, joka on löytänyt omat voimavaransa. Oma osaaminen ja sen myötä käsitys omasta itsestä ja minäpystyvyydestä ovat olennaisessa osassa. Oman osaamisen tunnistamisen avulla pyritäänkin juuri tähän omien voimavarojen löytämiseen.

Tässä katsauksessa voimaantuminen nähdään olennaisena nimenomaan osaamisen tunnistamisen näkökulmasta. Tunnistaessaan osaamistaan ihminen voi kokea, että hän osaa paljon asioita, ja myös muut voivat nähdä ne eli osaaminen tulee näkyväksi. Oman osaamisen tunnistaminen voi vaikuttaa voimaannuttavasti, koska osaamisen tunnistamisella on myönteisiä vaikutuksia yksilön minäkäsitykseen, itsetuntemukseen ja hyvinvointiin. Lisäksi oman osaamisen tunnistaminen voi avata edelleen erilaisia osallisuuden ja toimijuuden portteja, millä on myönteinen vaikutus kotoutumiseen. (Airaksinen \& Aittamaa 2019, 75.)

\section{Kokemuksia oman osaamisen tunnistamisesta}

SkiLLfie-työkalut on tarkoitettu käytettäviksi itsenäisesti, ohjatusti tai ryhmissä. Hankkeessa käytimme niitä ohjatun ryhmätoiminnan osana siten, että meillä oli käytössä useita eri kieliversioita tarpeen mukaan. Hyödynsimme ryhmän vertaistukea siten, että kävimme yhdessä läpi haastavia tilanteita sekä keskustelimme esille nousseista vaikeista asioista. Tarvittaessa apunamme oli tulkki. Kokemustemme perusteella oman 
osaamisen tunnistaminen saattoi parhaimmillaan lisätä itsetuntemusta esimerkiksi sen suhteen, mitä omia taitoja halutaan kehittää ja mitä ei. Voimaantumisen kokemusta näytti lisäävän se, että työkaluja käytetään ohjatusti.

Oman osaamisen tunnistaminen auttaa näkemään uusia toimintamahdollisuuksia: omaa osaamistaan tunnistaneet voivat saada samalla tietoa heitä kiinnostavista harrastus- tai vapaa-ajantoiminnoista tai esimerkiksi koulutuksista. Omaa osaamista kannattaakin rohkaistua käyttämään myös muualla kuin formaalissa koulutuksessa tai työelämässä, mikä kartuttaa sosiaalisia suhteita sekä lisää hyvinvointia. Lisäksi on hyvä huomata, että yksilöllinen ammattisuuntautuminen ja -mieltymykset pääsevät esiin vasta sosiaalisten kontaktien kautta (Joro 2019, 22).

\section{Ryhmässä tapahtuva työskentely - vertaistukea ja sosiaalista tunnustamista}

Ryhmässä tapahtuva työpajatyyppinen toiminta osoittautui toimivaksi oman osaamisen tunnistamista tukevaksi menetelmäksi silloin, kun hyödynsimme SkiLLfie-työkaluja. Ryhmätyöskentelyyn oli luontevasti liitoksissa sekä sosiaalisten suhteiden merkitys että vertaistuen hyödyt. Osallistujien kielitaidon tasot vaihtelivat, ja ryhmäläiset saivatkin toisiltaan apua vaikeiden sanamuotojen ymmärtämiseksi. Varsinkin niiden osallistujien kohdalla, joille ei ollut tarjolla oman osaamisen tunnistamisen itsearviointityökaluja heidän vahvimmilla kielillään, ryhmän tuen tarve korostui. Monet halusivat tutkia työvälineitä rinnakkain kahtena eri kieliversiona: niin omalla äidinkielellään kuin suomen kielellä.

On hyvä huomioida, että osaamisen kuvaileminen on vaikeaa vieraalla kielellä. Erityisen vaikeaa se on tilanteessa, jossa ei tiedetä, millaista osaamista ylipäätään tulisi kuvailla ja miten. Aluksi onkin tärkeää kiinnittää huomio siihen, miten osaaminen ymmärretään. Näkökulmia voi olla useita. Usein osaaminen liitetään ammatilliseen osaamiseen. Lisäksi on huomioitava kulttuurien mahdollisesti erilainen osaamiskäsitys: oppimiskäsitykset voivat poiketa eri kulttuureissa, jolloin myös osaamiskäsitys voi olla erilainen (Pusa 2015, 27). Riittävä ohjaus koettiin joka tapauksessa ensiarvoisen tärkeäksi etenkin silloin, kun oman osaamisen tunnistamisen tavoitteena on hyvinvointia tukeva, voimaannuttava kokemus.

Ryhmän tuki koettiin tärkeäksi myös silloin, kun oman osaamisen itsearviointia tehdessä nousi esiin sellaisia haastavia arjen kokemuksia, askarruttavia asioita tai suoranaisia kipukohtia, jotka vaativat purkamista 
sekä yhteistä keskustelua. Tällaisia olivat esimerkiksi kokemukset työelämään siirtymisen haasteista maahan muuttaneena henkilönä tai pelko kommunikoida suomen kielellä ja vaikeudet tutustua suomalaisiin, erityisesti siinä tapauksessa, kun oma senhetkinen kielitaidon taso koettiin matalaksi. Kokemustemme perusteella työpajatyyppinen oman osaamisen tunnistaminen ryhmässä voi toimia ponnahduslautana mielenkiintoisille ja hedelmällisille keskusteluille sekä vertaistuen mahdollistumiselle. Lisäksi ryhmätoimintaan on mahdollista liittää toiminnallisia elementtejä, joiden avulla voidaan helpottaa mahdollisia kieli-, kirjoitus- tai lukutaitoon liittyviä ongelmia. Omasta osaamisesta kertomisen apuna voi käyttää esimerkiksi kuvia.

Hankkeessa koetun perusteella sosiaalinen tunnustaminen on yksi olennainen osa oman osaamisen tunnistamisen prosessia. Työpajatyyppinen ryhmätyöskentely antaa tunnistamiselle luontevan lähtökohdan, kun osallistujilta saatu vertaispalaute on omiaan vahvistamaan ja tunnustamaan yksilön osaamisen arvoa. Lisäksi vertaisilta voi saada omaan osaamiseen liittyviä uusia näkökulmia, usein myös sellaisista asioista, joita on itse saattanut tottua pitämään itsestäänselvyyksinä.

Oman osaamisen tunnistamista on varminta tehdä ainakin alkuun ohjatusti - saattaahan omien mahdollisuuksien arviointi olla hankalaa itsenäisesti. Ohjaaja voi auttaa mahdollisuuksien tiedostamisessa sekä antaa vinkkejä oman osaamisen käyttö- ja kehittämismahdollisuuksissa. Kohderyhmää koskevat erityispiirteet ja mahdolliset haasteet, kuten esimerkiksi senhetkisen kielitaidon taso, on syytä tiedostaa.

\section{Kielitaitoon liittyvät sudenkuopat oman osaamisen tunnistamisen prosessissa}

Käytännön työssä havaitsimme, että mikäli oman osaamisen tunnistamisessa on tarkoituksena kuvailla tai kirjata omaa osaamista sellaisella kielellä, joka on itselle heikko, omia osaamisalueita pyritään usein hahmottamaan senhetkisen kielitaidon tason kautta. Kokemus heikosta kielitaidosta vaikutti myös kokemukseen omasta osaamisesta ja sen tunnistamisesta ja sai aikaan myös kokonaisvaltaisempia negatiivisia vaikutuksia. Kokemustemme perusteella kielitaito olikin juuri se syy, joka saattoi kääntää kokemuksen oman osaamisen tasosta ja sen tunnistamisesta joko myönteiseksi tai kielteiseksi (vrt. Lehto ym. 2018). Tästä syystä omaa osaamista olisi hyödyllistä pohtia omalla äidinkielellä, etenkin mikäli työskentelyn taustalla on ajatus voimavaralähtöisyydestä. Omat tunteet ja ajatukset 
osataan ilmaista täsmällisimmin omalla äidinkielellä (Alitolppa-Niitamo 1993, 40). Kielitaidon merkitys on tästä syystä perusteltua nostaa esille, kun tarkastellaan maahan muuttaneiden oman osaamisen tunnistamista voimavaralähtöisyyden näkökulmasta.

Kielitaito on sidoksissa koko elämään (Martin 2004, 181), ja kielitaidon väitetään myös olevan edellytys kaiken muun uuden oppimiselle (Alitolppa-Niitamo 1993, 38). Ryhmätyöpajoissa huomasimme, että omaa osaamista pyrittiin hahmottamaan suomen kielen taidon kautta etenkin silloin, kun siitä haluttiin viestiä suomen kielellä. Tilanteissa, joissa esimerkiksi omaan ammattiin liittyy vahvasti suomen kielen käyttö, oma ammattitaito saatettiin rinnastaa kielitaidon senhetkiseen tasoon. Tällöin oli mahdollista, että oma ammattitaito nähtiin puutteellisena riippuen kielitaidon tasosta. Tämän kaltainen kielitaidon määrittelemä käsitys omasta osaamisesta vaikuttaa negatiivisesti minäkuvaan ja omaan elämään Suomessa. Tästä syystä on eduksi, jos oman osaamisen itsearviointia on mahdollista tehdä myös omalla äidinkielellä, tarvittaessa tulkkausta apuna käyttäen. Lisäksi on hyvä huomata, että liian laajat "testipatteristot" yhdessä kielitaitovaatimusten kanssa voivat saada aikaan osaamattomuuden tunteen. Suomen kielen taitotaso ei kuitenkaan saisi vaikuttaa oman osaamisen tunnistamiseen, koska muutoin on vaarana, että henkilö arvioi omaa osaamistaan ainoastaan senhetkisen kielitaitonsa kautta (Airaksinen \& Aittamaa 2019, 75). Nämä asiat huomioiden oman osaamisen tunnistaminen on kokemustemme perusteella mahdollista suunnata mahdollisimman voimaannuttavaksi kokemukseksi.

\section{Lopuksi: osaamisen tunnistaminen voimavaralähtöisessä maahanmuuttajatyössä}

Oman osaamisen tunnistaminen voi parhaimmillaan saada aikaan myönteisiä vaikutuksia: se voi vaikuttaa positiivisesti tulevaisuuden suunnitelmiin, käsitykseen omasta osaamisesta ja kyvykkyydestä sekä laajemmin käsitykseen itsestä. Vaikutus voi olla voimaannuttava sekä vahvistaa myönteisesti yksilön minäkäsitystä ja motivaatiota. Lisäksi maahan muuttaneiden osaamisen tunnistamisella voi olla merkitystä myös kotoutumista edistävänä tekijänä: erilaisten vahvuusalueiden ja kiinnostuksen kohteiden rohkaisemana voi hakeutua esimerkiksi sellaisen harrastustoiminnan piiriin, jonka avulla voi edistää omaa kielitaitoa ja sosiaalisten yhteyksien muodostumista Suomessa. Olennaista kuitenkin on huomata, että 
kotoutumisen prosessiin osallistuu maahan muuttaneen henkilön lisäksi myös vastaanottava yhteisö (Työ- ja elinkeinoministeriö 2020).

On kiinnostava huomio, että oma osaaminen yhdistyy usein voimakkaasti juuri ammatilliseen osaamiseen tai kielitaitoon. Kokemus heikosta kielitaidosta vaikutti myös kokemukseen omasta osaamisesta. (Airaksinen \& Aittamaa 2019.) Jotta yksilö rohkaistuisi osallistumaan eri tavoin, tarvitaan luonnollisesti myös toisen osapuolen vastaanottavaa ja kannustavaa suhtautumista. Ympäristön asenteilla on siis erittäin suuri merkitys.

On hyvä tiedostaa kielitaidon aiheuttamat sudenkuopat oman osaamisen tunnistamisen prosessissa. Esimerkiksi Martin $(2004,180)$ kuvailee ympäristönsä kieltä taitamattoman työntekijän olevan umpikujassa niin ammatillisesti kuin inhimillisesti. Kun töissä täytyisi osata puhua, ymmärtää, lukea ja kirjoittaa suomea, kielitaidoton ei voi edetä uudenlaisiin työtehtäviin. Tämä pätee myös muussa kuin työhön liittyvässä ympäristössä. Toisaalta kokemustemme perusteella yhteinen tekeminen esimerkiksi harrastustoiminnassa on aivan mahdollista ilman yhteistä kieltäkin. Lisäksi osallistumisesta vapaan sivistystyön toimintaan voi saada todistuksen tai osaamismerkin, jolla on edelleen merkitystä työelämään tai koulutukseen hakeutumisessa. (Käyhkö ym. 2019, 44.) Käytännön ja yhteisen tekemisen kautta myös kielitaidolle annetaan mahdollisuus kehittyä eri konteksteissa. Olisikin hyödyllistä, että kieltä päästäisiin oppimaan sellaisessa ympäristössä, jossa tarvittavien käsitteiden oppiminen on luontevaa. (Vakimo 2013, 78.) Osaamis- ja vahvuusalueiden tiedostaminen edesauttaa hakeutumaan esimerkiksi erilaisiin harrastustoimintoihin, joissa omaa osaamista pääsee hyödyntämään. Tämä edistää kielitaidon ja sosiaalisten yhteyksien muodostumista Suomessa edelleen. Kielitaito linkittyykin osaltaan sosiaalisiin suhteisiin, jotka edelleen tukevat kielitaidon kehitystä (mm. Kruusvall 2002, 147).

Oman osaamisen tunnistaminen voi tarjota väylän omien voimavarojen tunnistamiseen ja kehittämiseen. Osaamisen tunnistaminen taas lisää vaikutusmahdollisuuksia omaan elämänkulkuun ja hyvinvointiin. Edellytykset osallisuuteen ja toimijuuteen kasvavat. Tässä katsauksessa kuvailtuihin Kotoa kohti työelämää -hankkeen kokemuksiin perustuen oman osaamisen tunnistaminen näyttää olevan toimiva menetelmä myös silloin, kun työskennellään voimavaralähtöisesti maahanmuuttajatyössä. Oman osaamisen tunnistamista tulisi vaalia erityisesti sosiaalisen tunnustamisen 
näkökulmasta edelleen. Hyvinvoinnin lisääntymisen ja voimaantumisen kannalta on olennaista, että omaa osaamista arvioidaan laaja-alaisesti - ei siis ainoastaan työelämän ja ammattiosaamisen näkökulmasta.

\section{LÄHTEET}

Airaksinen, A. \& Aittamaa, A.-M. 2019. "Tuntuu ihan vahvalta" - Itä-Suomen yliopiston Opinsauna-hankkeen oman osaamisen tunnistamisen työkalujen käytön vaikutukset. Itä-Suomen yliopisto. Filosofinen tiedekunta. Aikuiskasvatustieteen pro gradu -tutkielma. Saatavissa http://urn.fi/urn:nbn:fi:uef-20191381 (haettu 5.9.2020).

Ager, A. \& Strang, A. 2004. Indicators of integration: Final report. Home office development and practice report 28. London: Home Office. Saatavissa http://webarchive. nationalarchives.gov.uk/20110218141321/http:/rds.homeoffice.gov.uk/rds/pdfs04/ dpr28.pdf (haettu 6.9.2020).

Ager, A. \& Strang, A. 2008. Understanding integration: A conceptual framework. Journal of Refugee Studies 21 (2), 166-191.

Alitolppa-Niitamo, A. 1993. Kun kulttuurit kohtaavat: Matkaopas maahanmuuttajan kohtaamiseen ja kulttuurien väliseen vuorovaikutukseen. Helsinki: Sairaanhoitajien koulutussäätiö \& Suomen Mielenterveysseura.

Cattaneo, L. B. \& Chapman A. R. 2010. The process of empowerment. American Psychologist 65 (7), 646-659.

Cedefop. 2014. Terminology of European education and training policy. A selection of 130 key terms. European Centre for the development of vocational training. Luxembourg: Office for Official Publications of the European Communities. Saatavissa https://www.cedefop.europa.eu/files/4117_en.pdf (haettu 19.09.2019).

Hokkanen, L. 2017. Empowerment valtaistumisen ja voimaantumisen dialogina. Teoksessa M. Mäntysaari, A. Pohjola \& T. Pösö. 2017. Sosiaalityö ja teoria. Jyväskylä: PS-kustannus, 315-337

Hänninen, S. 2009. Voimaantumisen tarinat subjektiuden vahvistajana. Aikuiskasvatus $29(1), 4-13$.

Itä-Suomen yliopisto. 2020. Osaamisen tunnistaminen. Saatavissa https://www3.uef.fi/ web/opinsauna/osaamisen-tunnistaminen (haettu 06.09.2020).

Joro, T. 2019. Turvapaikanhakijoiden osaaminen yhteiskunnallisena voimavarana. Joensuu: Itä Suomen yliopisto. Saatavissa http://www.allyouthstn.fi/wp-content/ uploads/2019/05/Loppuraportti-2019-UEF-Osaamiskartoitukset.pdf (haettu 28.06.2020).

Karttunen, A. 2011. Näkökulmia validoinnista - Euroopan kautta Suomeen. Teoksessa A. Pehkonen (toim.) Tavoitteena työelämä: Maahanmuuttajien osaaminen näkyväksi. Kuopio: Savon koulutuskuntayhtymä, 11-35. 
Kruusvall, J. 2002. Social perception and individual resources of the integration process. Teoksessa M. Lauristin \& M. Heidmets (eds) The challenge of the Russian minority. Emerging Multicultural Democracy in Estonia. Tartu: Tarttu University Press, 117-162.

Käyhkö, K., Manninen, J. \& Pitkänen, M. 2019. Yhteisiä oppimisen tiloja kehittämässä: Kotoutumista ja kohtaamista tukevissa vapaan sivistystyön pilottihankkeissa opittua. Joensuu: University of Eastern Finland.

Lehto, L., Hakala, K. \& Eskola-Kronqvist, A. 2018. Oman osaamisen peili. Teoksessa T. Hirard \& A. Eskola-Kronqvist (toim.) Urareitti-hankkeen satoa - Uusia malleja korkeasti koulutettujen maahanmuuttajien kielikoulutukseen, ohjaukseen ja osaamisen tunnistamiseen. Hämeenlinna: Hämeen ammattikorkeakoulu, 211-216. Saatavilla https://www.theseus.fi/bitstream/handle/10024/152387/Urareitti_hankejulkaisu.pd$\mathrm{f}$ ? sequence $=1$ \&isAllowed $=\mathrm{y} \#$ Urareitti_hankejulkaisu.indd $\% 3 \mathrm{~A} .28052 \% 3 \mathrm{~A} 36318$ (haettu 28.06.2020).

Martin, M. 2004. Kenen kielitaito riittää? Teoksessa U. Aunola (toim.) Maahanmuuttajat ammattia oppimassa. Helsinki: Opetushallitus, 180-191.

Nivala, E. \& Ryynänen, S. 2019. Sosiaalipedagogiikka: kohti inhimillisempää yhteiskuntaa. Helsinki: Gaudeamus.

Otala, L. 2008. Osaamispääoman johtamisesta kilpailuetu. Porvoo: WSOY.

Pusa, M-L. 2015. Maahanmuuttajien osaaminen käyttöön - tunnistamisen lähtökohtia ja hyviä käytäntöjä. Teoksessa R. Metsänen, P. Pynnönen \& K. Kähkönen (toim.) Esteettä eteenpäin -maahanmuuttajien arviointi haku- ja valintavaiheessa. Hämeenlinna: Hämeen ammattikorkeakoulu, 23-29.

Pusa, M-L. 2017. Mitä on osaaminen? Sivustolla tekoihin.fi: tukea, tietoa ja materiaaleja maahanmuuttajien ammatilliseen koulutukseen. Saatavilla https://www.tekoihin.fi/ mita-on-osaaminen/ (haettu 27.06.2020).

Saloheimo, L. 2008. Opitun tunnistaminen ja tunnustaminen vapaassa sivistystyössä. Teoksessa A. Toom, J. Onnismaa \& A. Kajanto (toim.) Hiljainen tieto - tietämistä, toimimista, taitavuutta. Helsinki: Kansanvalistusseura ja Aikuiskasvatuksen tutkimusseura, 333-352.

Smith, L. \& Clayton, B. 2009. Recognising non-formal and informal learning: Participant insights and perspectives. A National Vocational Education and Training Research and Evaluation Program Report. National Centre for Vocational Education Research (NCVER).

Työ- ja elinkeinoministeriö. 2020. Maahanmuuttajien onnistunut kotoutuminen on monen tekijän summa. Saatavilla https:/valtioneuvosto.fi/-/1410877/maahanmuuttajien-onnistunut-kotoutuminen-on-monen-tekijan-summa (haettu 05.09.2020)

Vakimo, T. 2013. Aikuisten maahanmuuttajien oppimisvaikeudet. Teoksessa A. Alitolppa-Niitamo, S. Fågel \& M. Säävälä (toim.) Olemme muuttaneet - ja kotoudumme: Maahan muuttaneen kohtaaminen ammatillisessa työssä. Helsinki: Väestöliitto, 7490. 
Wilhelmsson, N. 2010. Osaamisen määrittely. Teoksessa T. Seppälä \& N. Wilhelmsson (toim.) Maahanmuuttajan osaamisen tunnistaminen: Maahanmuuttajataustaisen opintoihin hakeutuvan osaamisen tunnistaminen toisen asteen koulutuksessa. Helsinki: Helsingin yliopisto, koulutus- ja kehittämiskeskus Palmenia, 10-31.

Wilhelmsson, N. 2013. Maahanmuuttajien osaamisen tunnistaminen Helsingin Diakoniaopiston ammatillisissa työvoimapoliittisissa koulutuksissa. Teoksessa A. Alitolppa-Niitamo, S. Fågel \& M. Säävälä (toim.) Olemme muuttaneet - ja kotoudumme: Maahan muuttaneen kohtaaminen ammatillisessa työssä. Helsinki: Väestöliitto, 3243.

Zimmerman, M. 1995. Psychological empowerment: issues and illustrations. American Journal of Community Psychology 23 (5), 581-599. 